1855. Copies of each of these editions with less than the original number of engravings are occasionally offered for sale; but whether they have been reprinted, or have simply suffered mutilation, we are unable to state. The Historical Department has fortunately obtained a copy of ench of the genuine first editions of this great work. The octavo edition was acquired three or four years ago-the original folio copy quite recently. Curiously enough, the last was offered for sale in a catalogue issued by a dealer in fine and secondhand books in Liverpool, England, for a mere fraction of its original cost, and was promptly purchased. This edition was not dated, but the date of its publication is well known. It is an especially valuable addition to the growing Indian Collection in the Historical Department, from the fact that it contains twenty-five to thirty portraits of Indians belonging to tribes living within the present borders of this State. The portraits in both editions are very fine lithographs colored by hand. That they are excellent likenesses of the Indians whose names they bear is vouched for by the authors. They are full of life, representing the Indians in all the glories of paint, feathers, beads and blankets. It requires bright colors to show these chieftains and braves in their gala dresses. Some of the portraits are exceedingly striking, especially those of Blackhawk, Keokuk, Wapello, Mahaska, and his wife, Rantchewaime, Kishkekosh and Powesheik, as well as several of lesser note. "In the good time coming," doubtless many of these will be reproduced in oil, for the portrait gallery which will be one of the attractive features of the Iowa Historical Building. As data for such an undertaking they are simply invaluable.

\title{
PROCEEDINGS OF THE PIONEER LAW MAKERS.
}

Prior to 1896 the State legislature made provision for the publication of the Proceedings of our Pioneer Law Makers Association at each of the biennial reunions. But at the first session of the 26th General Assembly the bill making this provision was lost. At the late extra session, however, 
the proposition was renewed and passed. It is now incorporated in the new Code of Iowa, providing for the publication of twelve hundred copies of the proceedings of each reunion. At the proper time, and possibly in the belief that. the proceedings would not be published in pamphlet form, the Secretary failed to put them into proper shape for publication. The consequence was, that when the legislaturefinally provided for their publication the copy was still unprepared and its materials scattered. At this juncture the matter was taken up by Hon. B. F. Gue, the present Secretary of the Association, who proceeded to collect the necessary data for the pamphlet, so far as it can be accomplished at this late day. It is believed that the more impcrtant. materials were gathered up, though at least one of the addresses was lost, and the general proceedings doubtless very much abridged. Mr. Gue is entitled to the credit of putting them into the best possible shape, though some of the important and highly interesting features of the preceding volumes are necessarily omitted. The pamphlet will possess especial value from the fact that it presents in full the able and interesting, as well as historically valuable, address of Hon. John A. Kasson upon the exciting struggle for the erection of the State capitol. The addresses of Hon. Elijah Sells and Hon. Washington Galland are also interesting and possessed of much historic value, as well as the tributes to. the memory of U. S. Senator James F. Wilson, Judge George G. Wright and Gen. Ed Wright. It is to be regretted that. the volume is not as full and complete as its predecessors, but that is due to the causes we have set forth. Provision having been made for their regular publication, it is believed that future volumes will equal in interest and value those of 1886-94.

\section{THE PASSENGER-PIGEON.}

Forty years ago, when the writer came to Iowa, and for several years thereafter, Passenger-pigeons were often seen in this region in immense flocks. In fact, there were points in our State where these birds nested-"pigeon-roosts," as 
Copyright of Annals of Iowa is the property of State of Iowa, by \& through the State Historical Society of Iowa and its content may not be copied or emailed to multiple sites or posted to a listserv without the copyright holder's express written permission. However, users may print, download, or email articles for individual use. 